\title{
Effect of NPK Levels and Micronutrients with and without Liquid Biofertilizer on Physico-Chemical Properties of Soil in Maize
}

\author{
Dalavi Vishal Manohar*, Narendra Swaroop, Tarence Thomas and Arun Alfred David
}

Department of Soil Science and Agricultural Chemistry, [Naini Agricultural Institute], Sam Higginbottom University of Agriculture, Technology and Sciences, Prayagraj, U. P. India

*Corresponding author

\section{A B S T R A C T}

\begin{tabular}{l} 
Key w or d s \\
Maize, NPK, \\
$\begin{array}{l}\text { Physical chemical } \\
\text { properties of soil }\end{array}$ \\
\hline Article Info \\
\hline $\begin{array}{l}\text { Accepted: } \\
\text { 22 January } 2021 \\
\text { Available Online: } \\
\text { 10 February } 2021\end{array}$ \\
\hline
\end{tabular}

A field study was conducted on the "Effect of NPK Levels and Micronutrients with and without Liquid Biofertilizer on Soil Health and Yield Attributes of Maize (Zea Mays L.)" Cv. K-25" at the Soil Science \& Agricultural Chemistry Research Farm, Sam Higginbottom University of Agriculture, Technology and Sciences, Prayagraj during Kharif season 2018 and 2019. The soil of experimental area falls in order Inceptisol and soil texture was sandy loam. The result showed that in treatment $\mathrm{T}_{19}$ [140:80:50 NPK kg $\mathrm{ha}^{-1}+\mathrm{Zn}\left(20 \mathrm{~kg} \mathrm{ha}^{-1}\right)$ and Mn $\left(25 \mathrm{~kg} \mathrm{ha}^{-1}\right)+$ Azotobacter $\left(200 \mathrm{ml} \mathrm{ha}^{-1}\right)+$ PSB $\left(200 \mathrm{ml} \mathrm{ha}^{-}\right.$ $\left.{ }^{1}\right)$ ] bulk density (1.17 $\mathrm{Mg} \mathrm{m}^{-3}$ during 2018, $1.11 \mathrm{Mg} \mathrm{m}^{-3}$ during 2019), particle density (2.32 $\mathrm{Mg} \mathrm{m}^{-3}$ during 2018, $2.49 \mathrm{Mg} \mathrm{m}^{-3}$ during 2019), pore space (47.54\% during 2018, $48.87 \%$ during 2019), water holding capacity (39.75\% during 2018, $39.95 \%$ during 2019), Soil texture (58, 30, $12 \%$ sand, slit, clay during 2018 and 2019), Soil colour (10 YR 6/3 pale brown and 10 YR 4/3 dark brown during 2018 and 2019), pH 6.99 during 2018, 7.67 during 2019, EC $\left(0.87 \mathrm{dSm}^{-1}\right.$ during 2018, $0.80 \mathrm{dSm}^{-1}$ during 2019), organic carbon $(0.35 \%$ during 2018, $0.50 \%$ during 2019$)$, available nitrogen $\left(290.87 \mathrm{~kg} \mathrm{ha}^{-1}\right.$ during 2018, $317.58 \mathrm{~kg} \mathrm{ha}^{-1}$ during 2019), available phosphorus (22.39 kg ha-1 during $2018,22.28 \mathrm{~kg} \mathrm{ha}^{-1}$ during 2019), available potassium (291.94 kg ha ${ }^{-1}$ during 2018, 269.52 $\mathrm{kgha}^{-1}$ during 2019), available zinc (0.84 $\mathrm{mg} \mathrm{kg}^{-1}$ during 2018, $0.85 \mathrm{mg} \mathrm{kg}^{-1}$ during 2019), available manganese $\left(5.35 \mathrm{mg} \mathrm{kg}^{-1}\right.$ during $2018,5.66 \mathrm{mg} \mathrm{kg}^{-1}$ during 2019)as compared to $\mathrm{T}_{0}$ (absolute control).

\section{Introduction}

Maize is an important cereal crop which ranks the third after wheat and rice in the world. Maize is grown widely in many countries of the world (Onasanya et al., 2009). Maize which is botanically called (Zea mays L) belongs to the family Gramineae. Maize is one of the world's leading crops cultivated over an area of 139 million hectares with the production of about 600 million tonnes of grain. USA leads the largest area, followed by Brazil, china, Mexico and India. It is grown in almost all states of India occupying an area of 6.3 million hectares with the production and productivity of 11.3 million tonnes and 1.9 million tonnes per hectares respectively (Kumar et al., 2007). Maize grain contains 
about $70 \%$ carbohydrate, $10 \%$ protein, $4 \%$ oil, $2.3 \%$ crude fiber, $10.4 \%$ albuminoides, $1.4 \%$ ash (Choudhary, 1993). Along with this, it is rich in vitamin $\mathrm{A}$, vitamin $\mathrm{E}$, nicotinic acid, riboflavin and contains fairly high phosphorus than rice and sorghum. Its fodder and hay contain $7-10 \%$ protein, $15-36 \%$ fiber, 2.09$2.62 \%$ ether extract, $0.42-0.70 \%$ calcium, $0.28-0.29 \%$ phosphorus, $0.45 \%$ magnesium, $1.34 \%$ potassium and $56 \%$ carbohydrate, therefore, it has very nutritive fodder and hay. Besides food grain, fodder and feed, it has prime importance in textile, starch and big industries (Rai, 2006). Maize is also known as "Queen of cereals" and kind of fodder maize has been usually considered as poor man's crop and occupying the place in the rich communities due to its multifarious use as industrial food and feed crops (Suke et al., 2011). Fertilizer plays an important role in increasing the maize yield and their contribution to economy is very high. Balanced and optimum use of nitrogen, phosphorus and potassium as well assulphur fertilizer plays a pivotal role in increasing the yields of cereals. Though the yield potential of our present varieties is high enough, but it has not been explored fully due to some production constraints. Among the limiting factors; proper level and ratio of nitrogen and phosphorus are prime importance. Maize is a highly potential crop in Mudhol area (Ghataprabha Left Bank Canal) of Bagalkot district in North Karnataka. Nitrogen is a vital plant nutrient and a major determining factor required for maize production. It is very essential for plant growth and makes up 1-4\% of dry matter of the plants. Nitrogen is essential constituent of protein and is present in many other compounds of great physiological importance in plant metabolism. Nitrogen is called a basic constituent of life (Singh et al., 2010). Phosphorus has a great role in energy storage and transfer and closely related to cell division and development of maize. Phosphorus is a constituent of nucleic acid, phytin and phospho-lipid. Phosphorus compound acts as energy within plants. Phosphorus is essential for transformation of energy, in carbohydrate metabolism, in fat metabolism, in respiration of plant and early maturity of maize.

Micronutrient play an active role in the plant metabolic process starting from cell development to respiration, photosynthesis, chlorophyll formation, enzyme activity, hormones synthesis, nitrogen fixation etc. The micronutrients are going to play a major protective role in bringing stability and sustainability in food production. The role of macro (NPK) and micronutrients ( $\mathrm{Zn} \& \mathrm{Mn}$ ) is crucial in yields. Nitrogen is a primary constituent of proteins and thus all enzymes (Raun and Johnson, 1999). P is involved in almost all biochemical pathways as a component part of energy carrier compounds, ATP and ADP (Khalil, 2003). Six micronutrients i.e., $\mathrm{Mn}, \mathrm{Fe}, \mathrm{Cu}, \mathrm{Zn}, \mathrm{B}$ and $\mathrm{Mo}$ are known to be required for all higher plants (Welch, 1995). These have been well documented to be involved in photosynthesis, $\mathrm{N}$ - fixation, respiration and other biochemical pathways (Marschner and Romheld, 1991).

Liquid bio-fertilizers are special liquid formulation containing not only the desired beneficial microorganisms and their biological secretions, but also special cell Protestants or substances that encourage the formation of dormant spores or cysts for longer shelf life and tolerance to adverse conditions. Bio-fertilizers include mainly the nitrogen fixing, phosphate solubilizing and plant growth promoting microorganisms. Biofertilizer is a natural input that can be applied as a complement to, or as a substituent of chemical fertilizer in sustainable agriculture (Ebrahimpour et al., 2011). Bio-fertilizers benefiting the crop production are Azotobacter, Azospirillum, blue green algae, Azolla, P-solubilizing 
microorganisms, mycorrhizae and rhizobium (Selvakumar et al, 2009). Among the biofertilizers, Azotobacter represents the main group of heterotrophic, non-symbiotic, gram negative, free living nitrogen-fixing bacteria. They are capable of fixing an average $20 \mathrm{~kg}$ N/ha/year. The genus Azotobacter includes 6 species, with A. chroococcum most commonly inhabiting in various soils all over the world (Mahato et al., 2009).

\section{Materials and Methods}

The present study entitled "Effect of NPK Levels and Micronutrients with and without Liquid Biofertilizer on Soil Health and Yield Attributes of Maize (Zea Mays L.)Cv. K25 "comprise of a field experiment which was carried out at the Soil Science\& Agricultural Chemistry Research Farm, Sam Higginbottom University of Agriculture Technology and Sciences Prayagraj during Kharif season 2018 and 2019, which is located at $25^{\circ} 24^{\prime} 30^{\prime \prime} \mathrm{N}$ latitude, $81^{\circ} 51$ ' $10^{\prime \prime} \mathrm{E}$ longitude and $98 \mathrm{~m}$ above the mean sea level. The detail of the experimental site, soil and climate is described in this chapter together with the experimental design, layout plan, cultural practice and techniques employed for the parameters. The area of Prayagraj district comes under subtropical belt in the South East Uttar Pradesh, which experience extremely hot summer and fairly winter.

The maximum temperature of the location reaches up to $46^{\circ} \mathrm{C}-48^{0} \mathrm{C}$ and seldom falls as $4^{0} \mathrm{C}-5^{0} \mathrm{C}$. The relative humidity ranged between 20 to 94 percent. The average rainfall in this area is around $1100 \mathrm{~mm}$ annually. It comes under subtropical climate receiving the mean annual rainfall of about $1100 \mathrm{~mm}$, major rainfall from July to end of September. However, occasional precipitation was also not uncommon during winter. The winter months were cold while summer months were very hot and dry. The minimum temperature during the crop season was to be $27.1^{\circ} \mathrm{C}$ and the maximum is to be $39.94^{\circ} \mathrm{C}$. The minimum humidity was $57.70 \%$ and maximum was to be $75.37 \%$.

\section{Results and Discussion}

\section{Bulk density $\left(\mathrm{Mg} \mathrm{m}^{-3}\right)$}

The result of data were decrypted in Table 1 and Fig. 1 showed that maximum bulk density $\left(\mathrm{Mg} \mathrm{m}^{-3}\right)$ of soil were found in treatment $\mathrm{T}_{19}$ [140:80:50 NPK kg ha ${ }^{-1}+\mathrm{Zn}\left(20 \mathrm{~kg} \mathrm{ha}^{-1}\right)$ and Mn $\left(25 \mathrm{~kg} \mathrm{ha}^{-1}\right)+$ Azotobacter $\left(200 \mathrm{ml} \mathrm{ha}^{-1}\right)+$ PSB (200 ml ha $\left.\mathrm{m}^{-1}\right)$ (1.17 $\mathrm{Mg} \mathrm{m}^{-3}$ during 2018, $1.11 \mathrm{Mg} \mathrm{m}^{-3}$ during 2019 ), in comparison with control $\left(\mathrm{T}_{1}\right)$ i.e. $1.14 \mathrm{Mg} \mathrm{m}^{-3}$ during 2018, $1.15 \mathrm{Mg} \mathrm{m}^{-3}$ during 2019 while the minimum values of the result were found in treatment $\mathrm{T}_{0}$ (absolute control) respectively. These treatments were statistically at par with each other with the treatment $\left(\mathrm{T}_{18}\right)$ i.e., 1.14 $\mathrm{Mg} \mathrm{m}^{-3}$ during 2018 and $1.13 \mathrm{Mg} \mathrm{m}^{-3}$ during 2019 respectively, the mean value of bulk density of soil $\left(\mathrm{Mg} \mathrm{m}^{-3}\right)$ was found significantly different. It was also observed that the bulk density of soil was gradually increased with increasing the dose of NPK levels. The effect of NPK levels and micronutrient with and without liquid biofertilizer was also found significant. Because the presence of NPK levels and micronutrient with and without liquid bio fertilizers in optimum amount increases bulk density of soil. It contains higher amount of sand, silt and clay particle. As indicated enrichment of fine fractions i.e., silt and clay a part from the retention of dissolved O.M. leading to change in physical properties of soil. (Motior et al., 2011, Kumar et al., 2015, Jayprakash et al., 2005, Kumar et al., 2019)

\section{Particle density $\left(\mathrm{Mg} \mathrm{m}^{-3}\right)$}

The result of data decrypted in Table 1 and Fig. 1 observed maximum particle density 
$\left(\mathrm{Mgm}^{-3}\right)$ of soil were found in treatment $\mathrm{T}_{19}$ [140:80:50 NPK kg ha ${ }^{-1}+\mathrm{Zn}\left(20 \mathrm{~kg} \mathrm{ha}^{-1}\right)$ and Mn $\left(25 \mathrm{~kg} \mathrm{ha}^{-1}\right)+$ Azotobacter $\left(200 \mathrm{ml} \mathrm{ha}^{-1}\right)+$ PSB (200 ml ha $\left.{ }^{-1}\right)$ ] $\left(2.32 \mathrm{Mgm}^{-3}\right.$ during 2018, $2.49 \mathrm{Mgm}^{-3}$ during 2019 )was minimum values of the result were found in treatment $\mathrm{T}_{0}$ (absolute control) which was $2.27 \mathrm{Mgm}^{-3}$ during 2018 \& $2.48 \mathrm{Mgm}^{-3}$ during 2019 respectively, These treatments were statistically at par with the treatment $\left(\mathrm{T}_{18}\right)$ i.e. $2.16 \mathrm{Mgm}^{-3}$ during 2018 and $2.62 \mathrm{Mgm}^{-3}$ during 2019 respectively, the mean value of particle density of soil $\left(\mathrm{Mgm}^{-3}\right)$ was found significantly different. It was also observed that the particle density of soil was gradually increased with the effect of NPK levels and micronutrient with and without liquid biofertilizer on particle density of soil was also found significant. (Motior et al., 2005; Kumar et al., 2015; Jayprakash et al., 2005; Kumar et al., 2019)

\section{Pore space $(\%)$}

The result of data decrypted in Table 1 and Fig.1 showed maximum pore space $(\%)$ of soil in treatment $\mathrm{T}_{19}$ [140:80:50 NPK kg ha $+\mathrm{Zn}\left(20 \mathrm{~kg} \mathrm{ha}^{-1}\right)+\mathrm{Mn}\left(25 \mathrm{~kg} \mathrm{ha}^{-1}\right)+$ Azotobacter $\left(200 \mathrm{ml} \mathrm{ha}^{-1}\right)+$ PSB $(200 \mathrm{ml} \mathrm{ha}$ $\left.{ }^{1}\right)$ ] (47.54\% during 2018, $48.87 \%$ during 2019 while the minimum values of the result were found in treatment $\mathrm{T}_{0}$ (absolute control) which was $38.32 \%$ during 2018 and $38.98 \%$ 2019 respectively.

These treatments are statistically at par with each other and on par with the treatment $\left(\mathrm{T}_{18}\right)$ i.e., $46.49 \%$ during 2018 and $47.49 \%$ during 2019 respectively, Bulk density and pore space were recorded maximum in INM practice and recommended dose of NPK levels and micronutrient with and without liquid bio-fertilizer. (Kumar et al., 2019, Motior et al., 2005, Kumar et al., 2015, Jayprakash et al., 2005)

\section{Water holding capacity (\%)}

The result of data showed in Table 1 and Fig. 1 observed maximum water holding capacity (\%) of soil found in treatment $\mathrm{T}_{19}$ [140:80:50 NPK kg ha ${ }^{-1}+$ Zn $\left(20 \mathrm{~kg} \mathrm{ha}^{-1}\right)+$ Mn $(25 \mathrm{~kg}$ $\left.\mathrm{ha}^{-1}\right)+$ Azotobacter $\left(200 \mathrm{ml} \mathrm{ha}^{-1}\right)+$ PSB (200

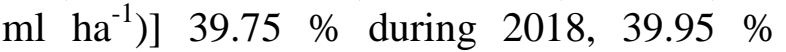
during 2019 while the minimum values of the result were found in treatment $\left(\mathrm{T}_{0}\right)$ absolute control which was $30.57 \%$ during 2018 and $30.27 \% 2019$ respectively. These treatments were statistically at par with the treatment $\left(\mathrm{T}_{18}\right)$ i.e., $39.62 \%$ during 2018 and 39.56 \%during 2019 respectively. (Kumar et $a l ., 2015)$ Water holding capacity of soil was found significantly different. It was also observed that the pore space of soil was gradually increased with an increase in dose of NPK levels and micronutrient and liquid Biofertilizer. The effect of NPK levels and micronutrient and liquid Biofertilizer on water holding capacity of soil was also found significant (Motior et al., 2005; Kumar et al., 2015; Jayprakash et al., 2005; Kumar et al., 2019).

\section{Soil texture}

The result of data showed in Table 1 and observed Soil Texture (\%) found in treatment $\mathrm{T}_{19}$ [140:80:50 NPK kg ha ${ }^{-1}+\mathrm{Zn}\left(20 \mathrm{~kg} \mathrm{ha}^{-1}\right)$ $+\operatorname{Mn}\left(25 \mathrm{~kg} \mathrm{ha}^{-1}\right)+$ Azotobacter $\left(200 \mathrm{ml} \mathrm{ha}^{-1}\right)$ + PSB (200 ml ha $\left.{ }^{-1}\right)$ ] 58, 30, $12 \%$ sand, slit, clay during 2018 and 2019 while the minimum values of the result were found in treatment $\left(\mathrm{T}_{0}\right)$ absolute control which was 60 , 35, $5 \%$ during 2018 and 2019 respectively. (Motior et al., 2005, Kumar et al., 2015, Jayprakash et al., 2005, Kumar et al., 2019)

\section{Soil colour}

The result of data showed in Table 1 and observed Soil Colour found in treatment $\mathrm{T}_{19}$ [140:80:50 NPK kg ha ${ }^{-1}+$ Zn $\left(20 \mathrm{~kg} \mathrm{ha}^{-1}\right)+$ 
Mn $\left(25 \mathrm{~kg} \mathrm{ha}^{-1}\right)+$ Azotobacter $\left(200 \mathrm{ml} \mathrm{ha}^{-1}\right)+$ PSB $\left.\left(200 \mathrm{ml} \mathrm{ha}^{-1}\right)\right] 10$ YR $6 / 3$ pale brown and 10 YR 4/3 dark brown during 2018 and 2019 while the minimum values of the result were found in treatment $\left(\mathrm{T}_{0}\right)$ absolute control which was 10 YR 7/3 very pale brown and 10YR 5/4 yellowish brown during 2018 and 2019 respectively. (Motior et al., 2005, Kumar et al., 2015, Jayprakash et al., 2005, Kumar et al., 2019)

\section{Soil pH (1:2.5) w/v}

The result of data decrypted in Table 2 and depicted in Fig. 2 showed that the maximum $\mathrm{pH}(1: 2) \mathrm{w} / \mathrm{v}$ were found in treatment $\mathrm{T}_{19}$ [140:80:50 NPK kg ha-1 + Zn $\left(20 \mathrm{~kg} \mathrm{ha}^{-1}\right)$ $+\operatorname{Mn}\left(25 \mathrm{~kg} \mathrm{ha}^{-1}\right)+$ Azotobacter $(200 \mathrm{ml} \mathrm{ha}$ $\left.{ }^{1}\right)+$ PSB (200 ml ha $\left.{ }^{-1}\right)$ ] 6.99 during 2018, 7.67 during 2019while the minimum values of the result were found in treatment $\left(\mathrm{T}_{0}\right)$ absolute control which was 6.69 during 2018 and 6.84 during 2019 respectively. Application of NPK fertilizer, micronutrient fertilizers and liquid Bio-fertilizers is one of the most important approaches on improving soil physicalchemical characters and maize grain using hybrid variety K-25 (Kanchan). These results indicated that the soil bulk densities were increased, whereas the soil porosity, field capacity and values of $\mathrm{pH}$ were increased by NPK levels and micronutrient with and without liquid bio-fertilizer at different stages. (Singh et al., 2017, Gupta et al., 2018, Kumar et al., 2015, Masih et al., 2005, Kumar et al., 2019)

\section{Soil electrical conductivity $\left(\mathrm{dSm}^{-1}\right)$}

The data depicted in Table 2 and Fig. 2 showed that the maximum electrical Conductivity $\left(\mathrm{dSm}^{-1}\right)$ were found significantly high in treatment $\mathrm{T}_{19}$ [140:80:50 NPK kg ha-1 $+\mathrm{Zn}\left(20 \mathrm{~kg} \mathrm{ha}^{-1}\right)+\mathrm{Mn}\left(25 \mathrm{~kg} \mathrm{ha}^{-1}\right)+$ Azotobacter (200 $\left.\mathrm{ml} \mathrm{ha}^{-1}\right)+$ PSB $\left(200 \mathrm{ml} \mathrm{ha}^{-}\right.$

$\left.\left.{ }^{1}\right)\right] \quad\left(0.87 \mathrm{dSm}^{-1}\right.$ during 2018, $0.80 \mathrm{dSm}^{-1}$ during 2019 while the minimum values of the result were found in treatment $\mathrm{T}_{0}$ (absolute control) which was $0.83 \mathrm{dSm}^{-1}$ during 2018 and $0.82 \mathrm{dSm}^{-1}$ during 2019 respectively. Table 2 depicted that the mean value of EC

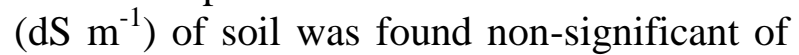
different levels of NPK. It was also observed that EC of soil were gradually increased with increasing dose of NPK levels and micronutrient with and without liquid Biofertilizer. The effect NPK levels and micronutrient on EC of soil was also found non-significant (Masih et al., 2018, Singh et al., 2017, Kumar et al., 2015).

\section{Organic carbon $(\%)$}

Usually, in sandy loam soils, organic matter content is low. Based on research studies during the course of two years, it has come with output that, the organically treated plot including bio-fertilizer and NPK levels, marked significantly higher organic carbon content and it varied from 0.31 to $0.96,0.37$ to 1.02 and 0.34 to $0.99 \%$, respectively, during 2018, 2019. The result of data depicted in Table 2 and Fig. 2 showed maximum organic carbon (\%) were found in treatment $\mathrm{T}_{19}$ [140:80:50 NPK kg ha ${ }^{-1}+\mathrm{Zn}\left(20 \mathrm{~kg} \mathrm{ha}^{-1}\right)$ $+\operatorname{Mn}\left(25 \mathrm{~kg} \mathrm{ha}^{-1}\right)+$ Azotobacter $\left(200 \mathrm{ml} \mathrm{ha}^{-1}\right)$ + PSB (200 ml ha $\left.{ }^{-1}\right)$ ] (0.35 \%during 2018, $0.50 \%$ during 2019)while the minimum values of the result were found in treatment $\left(\mathrm{T}_{0}\right)$ absolute control which was $0.26 \%$ during 2018 and $0.29 \%$ during 2019 respectively. These treatments were statistically at par with the treatment $\left(\mathrm{T}_{18}\right)$ i.e., $0.33 \%$ during 2018 and $0.56 \%$ during 2019 respectively, the mean value of organic carbon (\%) of soil was found significant of different levels of NPK and micronutrient. It was also observed that organic carbon (\%) of soil was gradually increased with increasing dose of NPK. effect NPK levels and micronutrient with and without liquid biofertilizer on organic carbon (\%) of soil was 
found significantly (Masih et al., 2018, Gupta et al., 2018, Kumar et al., 2015, Kumar et al., 2019)

\section{Available nitrogen $\left(\mathrm{Kg} \mathrm{ha}^{-1}\right)$}

The nitrogen has its major significant role in completion of crop life cycle. In contrast, by using different amount of NPK levels, micronutrient with and without liquid biofertilizers on sandy loam soil, the research work was conducted on maize crop during the two years. The observational studies after analyzed soil samples from respective field, integral effect of organics and inorganics found highest available $\mathrm{N}$ source. The available $\mathrm{N}$ among the treatment's ranges from 121.05 to 290.87 and 121.06 to 317.58 $\mathrm{kg} \mathrm{ha}{ }^{-1}$, respectively, observed data during 2018 and 2019 were presented in the Table 2 and described in Fig. 2. In clarity, treatment $\mathrm{T}_{19}$ [140:80:50 NPK kg ha ${ }^{-1}+\mathrm{Zn}\left(20 \mathrm{~kg} \mathrm{ha}^{-1}\right)$ $+\operatorname{Mn}\left(25 \mathrm{~kg} \mathrm{ha}^{-1}\right)+$ Azotobacter $(200 \mathrm{ml}$ ha $\left.{ }^{1}\right)+$ PSB $\left.\left(200 \mathrm{ml} \mathrm{ha}^{-1}\right)\right]\left(290.87 \mathrm{~kg} \mathrm{ha}^{-1}\right.$ during 2018, $317.58 \mathrm{~kg} \mathrm{ha}^{-1}$ during 2019 )while the minimum values of the result were found in treatment $\left(\mathrm{T}_{0}\right)$ absolute control which was $121.05 \mathrm{~kg} \mathrm{ha}^{-1}$ during 2018 and $121.06 \mathrm{~kg} \mathrm{ha}^{-1}$ during 2019 respectively. These treatments were statistically at par with the treatment $\left(\mathrm{T}_{18}\right)$ i.e., $253.17 \mathrm{~kg} \mathrm{ha}^{-1}$ during 2018 and $311.29 \mathrm{~kg}$ ha $^{-1}$ during 2019 respectively. (Meenaet al., 2018 (ac), Guptaet al., 2018, Ruth et al., 2018, Bharath et al., 2017(a), Singh et al., 2017). Increase in available $\mathrm{N}$ observed under organically treated plot, which might be due to mineralization effect of organic sources (Tabassum et al., 2010). It might be also due to the favorable soil conditions provided by NPK and liquid Biofertilizer addition might have helped in mineralization of additional soil $\mathrm{N}$ leading to build-up of higher available $\mathrm{N}$ and improved soil fertility (Santhy et al., 1998; Sarin et al., 1991; Kumar, 2014; Davari et al., 2012; Essan and Lattief, 2014).

\section{Available phosphorus (Kg ha $\left.{ }^{-1}\right)$}

The available $\mathrm{P}$ is the most limiting factor in sandy loam soil. However, it exists as an inorganic orthophosphate ion in soil having direct relationship with plant growth and development through regulation of protein synthesis. On the basis of research studies during two years, it has come with output that, the organically treated plot including liquid bio-fertilizer and NPK-levels, marked significantly highest available $\mathrm{P}$ in soil and it varied from 10.16 to 22.39 and 12.24 to 22.28 $\mathrm{kg} \mathrm{ha}^{-1}$, respectively, during 2018 and 2019 were presented in the Table 2 and described in Fig. 2. In clarity, treatment $\mathrm{T}_{19}$ [140:80:50 NPK kg ha ${ }^{-1}+$ Zn $\left(20 \mathrm{~kg} \mathrm{ha}^{-1}\right)+\mathrm{Mn}(25 \mathrm{~kg}$ $\left.\mathrm{ha}^{-1}\right)+$ Azotobacter $\left(200 \mathrm{ml} \mathrm{ha}^{-1}\right)+$ PSB (200 $\left.\left.\mathrm{ml} \mathrm{ha}^{-1}\right)\right]\left(22.39 \mathrm{~kg} \mathrm{ha}^{-1}\right.$ during 2018, $22.28 \mathrm{~kg}$ $\mathrm{ha}^{-1}$ during 2019 ) while the minimum values of the result were found in treatment $\left(\mathrm{T}_{0}\right)$ absolute control which was $10.16 \mathrm{~kg} \mathrm{ha}^{-1}$ during 2018 and $12.24 \mathrm{~kg} \mathrm{ha}^{-1}$ during 2019 respectively. These treatments were statistically at par with the treatment $\left(\mathrm{T}_{18}\right)$ i.e., $21.49 \mathrm{~kg} \mathrm{ha}^{-1}$ during 2018 and $22.24 \mathrm{~kg} \mathrm{ha}^{-}$ 1 during 2019 respectively, the highest available P in NPK levels and micronutrient with and without liquid bio-fertilizer treated plot resulted, might be due to effective solubilizations of native $\mathrm{P}$ in the soil through the release of various organic acids by Liquid bio-fertilizer. On another side it might be influenced by release of carbon dioxide $\left(\mathrm{CO}_{2}\right)$, which plays a dominant role in enhancing the $\mathrm{P}$ availability, during the decomposition of organic matter which forms carbonic acids, solubilizing certain primary minerals (Singh and Wanjari, 2007). In addition, bio-fertilizer could have maintained $\mathrm{P}$ reserve fairly at high level by forming a protective cover on sesquioxide's and this facilitates reduction in the P-fixing capacity of soil. (Meena et al., 2018; Gupta et al., 2018; Ruth et al., 2018; Bharath et al., 2017; Singh et al., 2017). 


\section{Available potassium $\left(\mathrm{Kg} \mathrm{ha}^{-1}\right)$}

The available $\mathrm{K}$ in soil is readily absorbed by the crop plant, as it held on the clay particles exchange sites. However, it exists as exchangeable form in soil having direct relationship with plant growth and development through regulation of protein and starch synthesis and also acts as energy unit for plants. On the basis of research during the two years, it has come with output that, the organically treated plot having higher clay content, having higher persistence in soil including liquid biofertilizer and NPK levels, marked significantly highest available $\mathrm{K}$ in soil and it varied from 145.83 to 291.94 and 196.52 to $269.52 \mathrm{~kg} \mathrm{ha}^{-1}$, respectively, during 2018, 2019 are presented in the Table 2 and described in Fig. 2. Among various treatment $\mathrm{T}_{19}$ [140:80:50 NPK kg ha- ${ }^{-1}+$ $\mathrm{Zn}\left(20 \mathrm{~kg} \mathrm{ha}^{-1}\right)+\mathrm{Mn}\left(25 \mathrm{~kg} \mathrm{ha}^{-1}\right)+$ Azotobacter $\left(200 \quad \mathrm{ml} \mathrm{ha}^{-1}\right)+\quad$ PSB $(200$ $\mathrm{ml} \mathrm{ha}^{-1}$ )] ( 291.94kg ha ${ }^{-1}$ during 2018, 269.52 $\mathrm{kg} \mathrm{ha}^{-1}$ during 2019 ) while the minimum values of the result were found in treatment $\left(\mathrm{T}_{0}\right)$ absolute control which was $145.83 \mathrm{~kg} \mathrm{ha}^{-1}$ during 2018 and $196.52 \mathrm{~kg} \mathrm{ha}^{-1}$ during 2019 respectively. These treatments are statistically at par with the treatment $\left(\mathrm{T}_{18}\right)$ i.e., $284.49 \mathrm{~kg}$ ha ${ }^{1}$ during2018 and $258.34 \mathrm{~kg} \mathrm{ha}^{-1}$ during 2019 respectively, the higher amount of available $\mathrm{K}$ in the micronutrient and liquid bio-fertilizer treated plot might have resulted, due to the fact on its application pronounced increased cation exchange capacity in soil, which is mainly capable of holding large amount of exchangeable K. Further, it helped in releasing exchangeable $\mathrm{K}$ from non-exchangeable pool. It could also ascribe due to the reduction in $\mathrm{K}$ fixation and release of $\mathrm{K}$ from reserved nonexchange site, which is held between inter lattice layer of clay or due to the interaction of organic matter with clay besides the direct addition of $\mathrm{K}$ to available pool of the soil (Kher and Minhas, 1991; Gupta et al., 2018; Ruth et al., 2018; Bharath et al., 2017; Singh et al., 2017).

\section{Available sulphur (kg ha $\left.{ }^{-1}\right)$}

The available sulphur is becoming recognized as the fourth macro-nutrient element in soil, as it readily absorbed by the crop plant in sulphate form, which pronounced more in organic state of a soil. However, it has direct relationship with plant growth in the formation of chlorophyll. On the basis of research studies during the two years, the outcome of the result says that, the organically treated plot including liquid biofertilizer and NPK-levels, marked significantly highest available sulphur in soil and it varied from 9.66 to 12.66 and 9.09 to $12.84 \mathrm{~kg} \mathrm{ha}^{-1}$, respectively, during 2018 and 2019 are presented in the Table 2 and described in Fig. 2. Alike other treatment, $\mathrm{T}_{19}$ [140:80:50 NPK kg ha ${ }^{-1}+\mathrm{Zn}\left(20 \mathrm{~kg} \mathrm{ha}^{-1}\right)$ and $\operatorname{Mn}\left(25 \mathrm{~kg} \mathrm{ha}^{-1}\right)+$ Azotobacter $\left(200 \mathrm{ml} \mathrm{ha}^{-1}\right)+$ PSB (200 ml ha $\left.{ }^{-1}\right)$ ] (12.66kg ha ${ }^{-1}$ during 2018, $12.84 \mathrm{~kg} \mathrm{ha}^{-1}$ during 2019) while the minimum values of the result were found in treatment $\left(\mathrm{T}_{0}\right)$ absolute control which was $9.66 \mathrm{~kg} \mathrm{ha}^{-1}$ during 2018 and $9.09 \mathrm{~kg} \mathrm{ha}^{-1}$ during 2019 respectively.

These treatments are statistically at par with the treatment $\left(\mathrm{T}_{18}\right)$ i.e., $12.20 \mathrm{~kg} \mathrm{ha}^{-}$ ${ }^{1}$ during2018 and $12.65 \mathrm{~kg} \mathrm{ha}^{-1}$ during 2019 respectively, Primarily, the increase in available sulphur was due to use of single superphosphate (SSP) as a source of $\mathrm{P}$, which contains appreciable amount of sulphur. In addition to this, the highest available sulphur in organic treatment might be attributed to mineralization of available NPKS nutrients from liquid bio-fertilizer, another reason might be that, the suitable soil conditions under organic sources might have promoted for mineralization of nutrients and leading to build-up higher NPKS (Agarwal et al., 2010 and Ravankar et al., 2005; Meena et al., 2018; Gupta et al., 2018; Ruth et al., 2018; Bharath et al., 2017; Singh et al., 2017). 
Table.1 Effect of NPK levels and micronutrient with and without liquid bio-fertilizer on physical properties of Soil 2018 and 2019

\begin{tabular}{|c|c|c|c|c|c|c|c|c|c|c|c|c|c|c|}
\hline \multirow{2}{*}{ 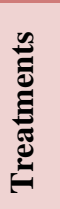 } & \multicolumn{2}{|c|}{$\begin{array}{c}\text { Bulk } \\
\text { Density } \\
\left(\mathrm{Mg} \mathrm{m}^{-3}\right)\end{array}$} & \multicolumn{2}{|c|}{$\begin{array}{l}\text { Particle } \\
\text { Density } \\
\left(\mathbf{M g ~ m}^{-3}\right)\end{array}$} & \multicolumn{2}{|c|}{$\begin{array}{c}\text { Pore space } \\
(\%)\end{array}$} & \multicolumn{2}{|c|}{$\begin{array}{c}\text { Water holding } \\
\text { capacity }(\%)\end{array}$} & \multicolumn{4}{|c|}{ Percentage of sand, silt and clay $(\%)$} & \multicolumn{2}{|c|}{ Percentage of sand, silt and clay $(\%)$} \\
\hline & 2018 & 2019 & 2018 & 2019 & 2018 & 2019 & 2018 & 2019 & Sand & Silt & Clay & Soil texture & Dry & Wet \\
\hline $\mathbf{T}_{1}$ & 1.14 & 1.15 & 2.27 & 2.48 & 38.32 & 38.98 & 30.57 & 30.27 & 60 & 35 & 5 & Sandy loam & 10 YR $7 / 3$ very pale brown & 10YR 5/4 yellowish brown \\
\hline $\mathbf{T}_{2}$ & 1.14 & 1.15 & 2.68 & 2.62 & 39.44 & 40.68 & 31.75 & 31.68 & 60 & 30 & 10 & Sandy loam & 10 YR $7 / 4$ very pale brown & 10 YR 5/3 brown \\
\hline $\mathbf{T}_{3}$ & 1.2 & 1.13 & 2.64 & 2.56 & 40.62 & 40.76 & 31.89 & 31.75 & 62 & 32 & 6 & Sandy loam & 10 YR 3/3 pale brown & 10 YR 4/4 dark yellowish brown \\
\hline $\mathbf{T}_{4}$ & 1.18 & 1.11 & 2.49 & 2.56 & 40.62 & 40.95 & 32.02 & 31.95 & 58 & 30 & 12 & Sandy loam & 10 YR $6 / 3$ pale brown & 10 YR 4/2 dark brown \\
\hline $\mathbf{T}_{5}$ & 1.15 & 1.05 & 2.47 & 2.85 & 40.77 & 41.1 & 32.15 & 32.42 & 60 & 30 & 10 & Sandy loam & $\begin{array}{c}10 \text { YR 6/4 light yellowish } \\
\text { brown }\end{array}$ & 10 YR 3/3 dark brown \\
\hline $\mathbf{T}_{6}$ & 1.14 & 1.11 & 2.32 & 2.62 & 41.51 & 41.8 & 32.18 & 32.72 & 55 & 35 & 10 & Sandy loam & 10 YR $6 / 3$ pale brown & 10 YR 4/3 dark brown \\
\hline $\mathbf{T}_{7}$ & 1.15 & 1.11 & 2.43 & 2.63 & 41.85 & 41.84 & 32.84 & 33.25 & 58 & 35 & 7 & Sandy loam & 10 YR $7 / 3$ very pale brown & 10 YR 4/4 dark yellowish brown \\
\hline $\mathbf{T}_{8}$ & 1.13 & 1.13 & 2.62 & 2.62 & 41.89 & 42.51 & 33.42 & 33.65 & 55 & 36 & 9 & Sandy loam & $\begin{array}{c}10 \text { YR 6/4 light yellowish } \\
\text { brown }\end{array}$ & 10 YR 5/4 yellowish brown \\
\hline $\mathbf{T}_{9}$ & 1.15 & 1.09 & 2.64 & 2.53 & 42.51 & 42.52 & 33.51 & 34.01 & 55 & 38 & 7 & Sandy loam & 10 YR $6 / 3$ pale brown & 10 YR 4/3 dark yellowish brown \\
\hline $\mathbf{T}_{10}$ & 1.14 & 1.11 & 2.43 & 2.49 & 42.52 & 42.56 & 34.51 & 35.12 & 55 & 36 & 9 & Sandy loam & 10 YR $3 / 3$ pale brown & 10 YR 4/4 dark yellowish brown \\
\hline $\mathbf{T}_{11}$ & 1.18 & 1.13 & 2.28 & 2.73 & 42.53 & 42.83 & 35.42 & 35.72 & 57 & 35 & 8 & Sandy loam & 10 YR $6 / 3$ pale brown & 10 YR 4/2 dark brown \\
\hline $\mathbf{T}_{12}$ & 1.18 & 1.11 & 2.36 & 2.62 & 42.53 & 43.17 & 36.55 & 36.36 & 55 & 35 & 10 & Sandy loam & $\begin{array}{c}10 \text { YR 6/4 light yellowish } \\
\text { brown }\end{array}$ & 10 YR 3/3 dark brown \\
\hline $\mathbf{T}_{13}$ & 1.14 & 1.13 & 2.16 & 2.56 & 42.89 & 43.28 & 37.05 & 36.89 & 58 & 35 & 7 & Sandy loam & 10 YR 3/3 pale brown & 10 YR 4/4 dark yellowish brown \\
\hline $\mathbf{T}_{14}$ & 1.17 & 1.11 & 2.32 & 2.52 & 43.28 & 43.83 & 37.29 & 37.39 & 55 & 36 & 9 & Sandy loam & 10 YR $7 / 3$ very pale brown & 10TR 5/4 yellowish brown \\
\hline $\mathbf{T}_{15}$ & 1.15 & 1.13 & 2.32 & 2.4 & 43.83 & 44.54 & 38.15 & 37.75 & 55 & 35 & 10 & Sandy loam & 10 YR 7/4 very pale brown & 10 YR 5/3 brown \\
\hline T16 & 1.18 & 1.13 & 2.28 & 2.49 & 44.28 & 44.95 & 38.82 & 38.66 & 56 & 32 & 11 & Sandy loam & 10 YR $3 / 3$ pale brown & 10 YR 4/4 dark yellowish brown \\
\hline $\mathbf{T}_{17}$ & 1.14 & 1.11 & 2.36 & 2.73 & 44.56 & 45.23 & 39.08 & 38.73 & 60 & 30 & 10 & Sandy loam & 10 YR $6 / 3$ pale brown & 10 YR 4/2 dark brown \\
\hline $\mathbf{T}_{18}$ & 1.14 & 1.13 & 2.16 & 2.62 & 46.49 & 47.49 & 39.62 & 39.56 & 62 & 32 & 6 & Sandy loam & $\begin{array}{c}10 \text { YR 6/4 light yellowish } \\
\text { brown }\end{array}$ & 10 YR 3/3 dark brown \\
\hline $\mathbf{T}_{19}$ & 1.17 & 1.11 & 2.32 & 2.49 & 47.54 & 48.87 & 39.75 & 39.95 & 58 & 30 & 12 & Sandy loam & 10 YR $6 / 3$ pale brown & 10 YR 4/3 dark brown \\
\hline & NS & NS & NS & NS & S & $\mathrm{S}$ & $\mathrm{S}$ & $\mathrm{S}$ & & & & & & \\
\hline & - & - & - & - & 1.623 & 1.537 & 1.873 & 1.874 & & & & & & \\
\hline & - & - & - & - & 3.279 & 3.108 & 3.786 & 3.789 & & & & & & \\
\hline
\end{tabular}


Table.2 Effect of NPK levels and micronutrient with and without liquid bio-fertilizer on chemical properties of Soil 2018 and 2019

\begin{tabular}{|c|c|c|c|c|c|c|c|c|c|c|c|c|c|c|c|c|c|c|}
\hline \multirow{2}{*}{ 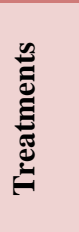 } & \multicolumn{2}{|c|}{$\begin{array}{c}P^{\mathrm{H}}(1: 2.5) \\
w / v\end{array}$} & \multicolumn{2}{|c|}{$\begin{array}{c}\text { Electric } \\
\text { conductivity } \\
\left(\mathrm{dSm}^{-1}\right)\end{array}$} & \multicolumn{2}{|c|}{$\begin{array}{c}\text { Organic } \\
\text { carbon }(\%)\end{array}$} & \multicolumn{2}{|c|}{$\begin{array}{l}\text { Available Nitrogen } \\
\qquad\left(\mathrm{kg} \mathrm{ha}^{-1}\right)\end{array}$} & \multicolumn{2}{|c|}{$\begin{array}{c}\text { Available } \\
\text { Phosphorous } \\
\left(\mathrm{kg} \mathrm{ha}^{-1}\right)\end{array}$} & \multicolumn{2}{|c|}{$\begin{array}{c}\text { Available } \\
\text { Potassium } \\
\left(\mathrm{kg} \mathrm{ha}^{-1}\right)\end{array}$} & \multicolumn{2}{|c|}{$\begin{array}{l}\text { Available } \\
\text { sulphur } \\
\left(\mathrm{kg} \mathrm{ha}^{-1}\right)\end{array}$} & \multicolumn{2}{|c|}{$\begin{array}{l}\text { Available Zinc } \\
\qquad\left(\mathrm{mg} \mathrm{kg}^{-1}\right)\end{array}$} & \multicolumn{2}{|c|}{$\begin{array}{c}\text { Available } \\
\text { Manganese } \\
\left(\mathrm{mg} \mathrm{kg}^{-1}\right)\end{array}$} \\
\hline & 2018 & 2019 & 2018 & 2019 & 2018 & 2019 & 2018 & 2019 & 2018 & 2019 & 2018 & 2019 & 2018 & 2019 & 2018 & 2019 & 2018 & 2019 \\
\hline $\mathbf{T}_{1}$ & 6.69 & 6.84 & 0.83 & 0.82 & 0.26 & 0.29 & 121.05 & 121.06 & 10.16 & 12.24 & 145.83 & 196.52 & 9.66 & 9.09 & 0.62 & 0.65 & 3.94 & 4.14 \\
\hline $\mathbf{T}_{2}$ & 6.84 & 6.62 & 0.79 & 0.83 & 0.27 & 0.3 & 125.77 & 122.05 & 12.2 & 12.51 & 174.14 & 202.15 & 9.84 & 9.85 & 0.63 & 0.68 & 4.04 & 4.2 \\
\hline $\mathbf{T}_{3}$ & 6.78 & 7.76 & 0.84 & 0.86 & 0.29 & 0.33 & 155.64 & 125.77 & 12.29 & 13.21 & 207.75 & 202.15 & 10.58 & 9.94 & 0.65 & 0.72 & 4.16 & 4.23 \\
\hline $\mathbf{T}_{4}$ & 6.85 & 7.79 & 0.85 & 0.87 & 0.34 & 0.3 & 170.92 & 144.64 & 12.9 & 13.86 & 217.11 & 211.5 & 10.94 & 10.16 & 0.65 & 0.73 & 4.19 & 4.24 \\
\hline$T_{5}$ & 6.95 & 6.79 & 0.83 & 0.82 & 0.42 & 0.31 & 193.37 & 155.64 & 13.36 & 14.12 & 218.94 & 213.34 & 10.94 & 10.38 & 0.66 & 0.73 & 4.2 & 4.3 \\
\hline $\mathrm{T}_{6}$ & 6.75 & 7.75 & 0.8 & 0.85 & 0.42 & 0.36 & 199.47 & 157.27 & 13.86 & 14.17 & 222.7 & 217.11 & 11.09 & 10.66 & 0.69 & 0.75 & 4.24 & 4.31 \\
\hline $\mathbf{T}_{7}$ & 6.92 & 7.91 & 0.82 & 0.89 & 0.4 & 0.39 & 200.31 & 180.8 & 14.12 & 14.6 & 224.6 & 218.94 & 11.1 & 10.85 & 0.71 & 0.75 & 4.29 & 4.33 \\
\hline $\mathbf{T}_{8}$ & 6.67 & 6.81 & 0.84 & 0.87 & 0.39 & 0.47 & 214.29 & 193.37 & 14.58 & 14.72 & 230.22 & 230.25 & 11.16 & 10.92 & 0.71 & 0.75 & 4.29 & 4.41 \\
\hline $\mathbf{T}_{9}$ & 6.91 & 7.77 & 0.82 & 0.85 & 0.39 & 0.36 & 218.47 & 193.37 & 14.84 & 14.92 & 230.22 & 230.26 & 11.34 & 11.15 & 0.72 & 0.76 & 4.3 & 4.44 \\
\hline $\mathbf{T}_{10}$ & 6.76 & 6.8 & 0.83 & 0.81 & 0.41 & 0.31 & 221.6 & 194.94 & 15.94 & 15.26 & 230.26 & 233.96 & 11.34 & 11.36 & 0.73 & 0.76 & 4.35 & 4.47 \\
\hline$T_{11}$ & 6.88 & 7.64 & 0.8 & 0.79 & 0.42 & 0.26 & 223.05 & 218.45 & 16.19 & 15.84 & 233.96 & 235.83 & 11.36 & 11.55 & 0.74 & 0.78 & 4.36 & 4.48 \\
\hline$T_{12}$ & 6.93 & 6.83 & 0.76 & 0.82 & 0.45 & 0.31 & 230.18 & 221.6 & 16.59 & 15.94 & 237.7 & 235.84 & 11.54 & 11.85 & 0.75 & 0.78 & 4.39 & 4.5 \\
\hline$T_{13}$ & 6.61 & 7.85 & 0.85 & 0.87 & 0.41 & 0.39 & 231.11 & 237.41 & 17.51 & 16.18 & 241.44 & 235.87 & 11.65 & 11.91 & 0.76 & 0.79 & 4.4 & 4.59 \\
\hline$T_{14}$ & 6.84 & 6.78 & 0.8 & 0.82 & 0.41 & 0.4 & 237.41 & 240.54 & 18.32 & 16.53 & 241.45 & 237.7 & 11.65 & 12.06 & 0.77 & 0.8 & 4.41 & 4.6 \\
\hline$T_{15}$ & 6.85 & 7.71 & 0.78 & 0.8 & 0.41 & 0.36 & 238.47 & 245.25 & 18.99 & 17.28 & 241.46 & 241.46 & 11.74 & 12.22 & 0.77 & 0.81 & 4.5 & 4.61 \\
\hline T16 & 6.88 & 6.88 & 0.81 & 0.8 & 0.27 & 0.49 & 240.54 & 253.12 & 21.33 & 20.16 & 243.31 & 252.61 & 12.16 & 12.35 & 0.79 & 0.81 & 4.59 & 5.25 \\
\hline$T_{17}$ & 6.93 & 6.93 & 0.79 & 0.76 & 0.29 & 0.62 & 244.82 & 289.28 & 21.38 & 21.26 & 258.33 & 252.63 & 12.17 & 12.46 & 0.82 & 0.81 & 5 & 5.43 \\
\hline $\mathrm{T}_{18}$ & 6.61 & 6.61 & 0.82 & 0.85 & 0.33 & 0.56 & 253.17 & 311.29 & 21.49 & 22.24 & 284.49 & 258.34 & 12.2 & 12.65 & 0.83 & 0.81 & 5.01 & 5.64 \\
\hline \multirow[t]{4}{*}{$T_{19}$} & 6.99 & 7.67 & 0.87 & 0.8 & 0.35 & 0.5 & 290.87 & 317.58 & 22.39 & 22.28 & 291.94 & 269.52 & 12.26 & 12.84 & 0.84 & 0.85 & 5.35 & 5.66 \\
\hline & NS & NS & NS & NS & S & S & $S$ & S & S & S & S & S & $\mathrm{S}$ & S & $\mathrm{S}$ & S & S & $\mathrm{S}$ \\
\hline & - & - & - & - & 0.027 & 0.103 & 54.346 & 74.187 & 2.604 & 1.926 & 25.956 & 9.843 & 0.026 & 0.0321 & 0.022 & 0.03 & 0.178 & 0.159 \\
\hline & - & - & - & - & 0.556 & 0.208 & 109.856 & 149.962 & 5.265 & 3.893 & 52.467 & 19.897 & 0.053 & 0.0649 & 0.047 & 0.063 & 0.361 & 0.323 \\
\hline
\end{tabular}


Fig.1 Effect of NPK levels and micronutrient with and without liquid bio-fertilizer on physical properties of Soil2018 and 2019

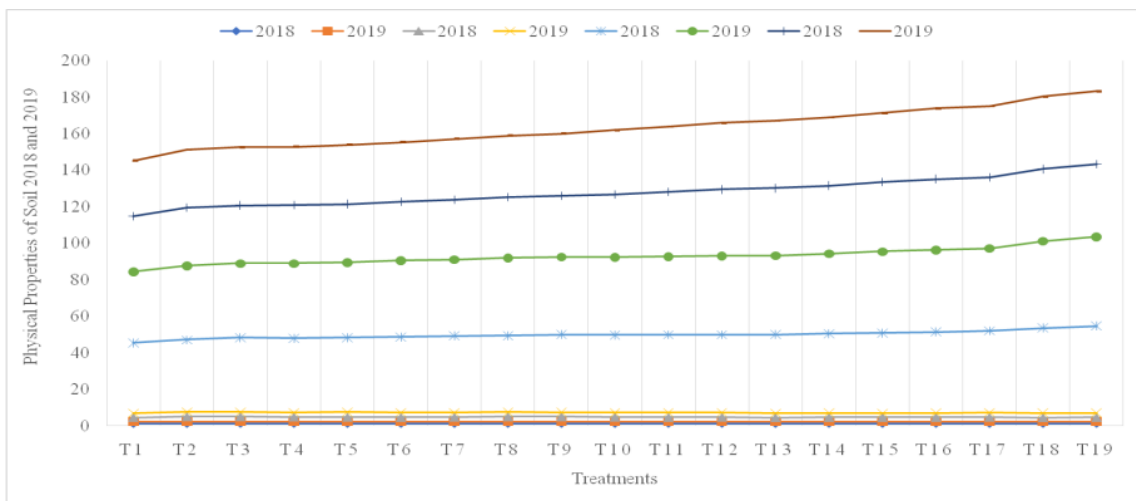

Fig.2 Effect of NPK levels and micronutrient with and without liquid bio-fertilizer on chemical properties of Soil2018 and 2019

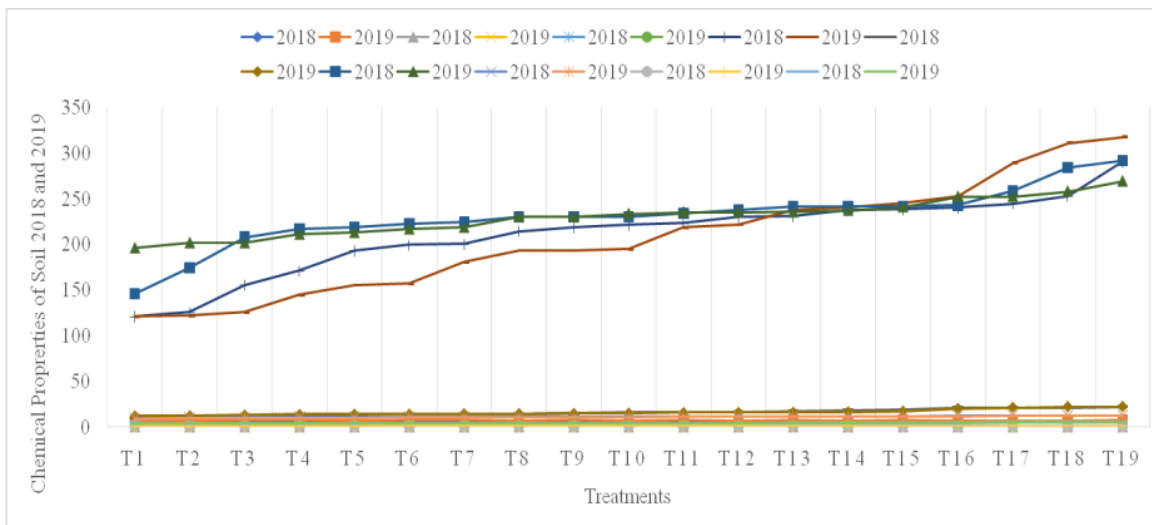

\section{Available zinc ( $\left.\mathrm{mg} \mathrm{kg}^{-1}\right)$}

Available zinc in the soil has its synergetic effect with available zinc in estimated soil samples from the experimental plot. Addition to this, zinc showed positive response with micronutrient treated plots in combination of liquid bio-fertilizers and NPK levels; this is happened when sandy loam soil is treated especially with micronutrient, as helps increasing clay content of soil by means of holding zinc in cheated form for longer time. Hence, leaching cannot take place. Outcome of the result from the two years says that, the organically treated plot including liquid biofertilizer and NPK levels, marked significantly highest. Available zinc in soil and it varied from 0.62 to 0.84 and 0.65 to $0.85 \mathrm{mg} \mathrm{kg}^{-1}$, respectively, during 2018 and 2019 are presented in Table 2 and described in Fig. 2. The results further showed that, organically treated plots marked highest available zinc in the treatments $\mathrm{T}_{19}$ [140:80:50 NPK kg ha ${ }^{-1}+\mathrm{Zn}\left(20 \mathrm{~kg} \mathrm{ha}^{-1}\right)+\mathrm{Mn}(25 \mathrm{~kg}$ $\left.\mathrm{ha}^{-1}\right)+$ Azotobacter $\left(200 \mathrm{ml} \mathrm{ha}^{-1}\right)+$ PSB $(200$ $\left.\mathrm{ml} \mathrm{ha}{ }^{-1}\right)$ ] ( $0.84 \mathrm{mg} \mathrm{kg}^{-1}$ during 2018, $0.85 \mathrm{mg}$ $\mathrm{kg}^{-1}$ during 2019 ) while the minimum values of the result were found in treatment $\left(\mathrm{T}_{0}\right)$ absolute control which was $0.62 \mathrm{mg} \mathrm{kg}^{-1}$ during 2018 and $0.65 \mathrm{mg} \mathrm{kg}^{-1}$ during 2019 respectively. These treatments are statistically at par with the treatment $\left(\mathrm{T}_{18}\right)$ i.e., $0.83 \mathrm{mg}$ $\mathrm{kg}^{-1}$ during2018 and $0.81 \mathrm{mg} \mathrm{kg}^{-1}$ during 2019 respectively, as we know, zinc is known to 
form relatively stable chelates with organic legends, in order to minimize their susceptibility with regard to adsorption, fixation and precipitation. Hence, the highest available zinc might have obtained in organic amended plots. On other side, amount of nutrients added, reaction time in soil, rate of extraction by roots, nature and amount of clay minerals, micronutrient content are the governing factors could have responded well with transformation of zinc in soils. (Jat, et al., 2014, Subehia, et al., 2011, Mishra et al.,2019, Gupta et al., 2018, Kumar et al., 2017, Saad et al., 2017, Singh et al., 2016)

\section{Available manganese ( $\left.\mathrm{mg} \mathrm{kg}^{-1}\right)$}

The most often occurring wide spread deficiency in sandy loam soils because of highly immobile complex nature of an element. Similar phenomenon was noticed that of available Manganese content in soil, where manganese availability has also gone down gradually on addition of organic matter by formation of manganese complexes, as described in the experiment. The data pertaining to manganese availability in soil showed that, significant variation existed among the different treatments. The range of available manganese was ranged from 3.94 to 5.35 and 4.14 to $5.66 \mathrm{mg} \mathrm{kg}^{-1}$, respectively, during 2018, 2019, are presented in the Table 2 and depicted graphically in Fig. 2. In contrast, from various treatment, $\mathrm{T}_{19}$ [140:80:50 NPK kg ha ${ }^{-1}+\mathrm{Zn}\left(20 \mathrm{~kg} \mathrm{ha}^{-1}\right)+$ $\operatorname{Mn}\left(25 \mathrm{~kg} \mathrm{ha}^{-1}\right)+$ Azotobacter $\left(200 \mathrm{ml} \mathrm{ha}^{-1}\right)+$ PSB $\left.\left(200 \mathrm{ml} \mathrm{ha}^{-1}\right)\right]$ (5.35 $\mathrm{mg} \mathrm{kg}^{-1}$ during 2018, $5.66 \mathrm{mg} \mathrm{kg}^{-1}$ during 2019) while the minimum values of the result were found in treatment $\left(\mathrm{T}_{0}\right)$ absolute control which was $3.94 \mathrm{mg} \mathrm{kg}^{-1}$ during 2018 and $4.14 \mathrm{mg} \mathrm{kg}^{-1}$ during 2019 respectively. These treatments are statistically at par with the treatment $\left(\mathrm{T}_{18}\right)$ i.e., $5.01 \mathrm{mg}$ $\mathrm{kg}^{-1}$ during2018 and $5.64 \mathrm{mg} \mathrm{kg}^{-1}$ during 2019 respectively. (Longchamp et al., 2016, Gyanendra et al., 2015, Singh et al., 2016)
In conclusion the present investigation, it was apparent that application of $\mathrm{N}$ and $\mathrm{P}$ fertilizer in treatment $\mathrm{T}_{19}$ [140:80:50 NPK kg ha ${ }^{-1}+\mathrm{Zn}$ $\left(20 \mathrm{~kg} \mathrm{ha}^{-1}\right)+\operatorname{Mn}\left(25 \mathrm{~kg} \mathrm{ha}^{-1}\right)+$ Azotobacter $\left(200 \mathrm{ml} \mathrm{ha}^{-1}\right)+$ PSB $\left.\left(200 \mathrm{ml} \mathrm{ha}^{-1}\right)\right]$ was found on physical and chemical parameters of soil such as bulk density, particle density, \% pore space, water holding capacity, Soil texture, Soil colour, EC, $\mathrm{pH}$, organic carbon, available NPKS and available micronutrient ( $\mathrm{Zn}, \mathrm{Mn}$ ) than other treatment combinations. \%pore space, $\mathrm{pH}$ and $\mathrm{EC}$ are non-significant. Thus it can be concluded that different levels of $\mathrm{N}$ and $\mathrm{P}$ fertilizer improved soil available nutrient, increased soil available nitrogen, phosphorus, potassium and electrical conductivity. However, $\mathrm{pH}$ of soil increased and also among the treatments $\mathrm{T}_{19}$ recorded the best treatment which increased the availability of nutrient and influenced on physical properties of soil.

\section{Acknowledgements}

The authors are grateful to the advisor SHUATS, Department of Soil Science and Agricultural Chemistry, Naini Agriculture Institute, for taking their keen interest and encouragement to carry out the research work.

\section{References}

Agarwal P.P., Samir, G. Al. and El-Nakhlawy Fathy, S., (2010) Effect of integrated use of organic and inorganic fertilizer on NPK uptake efficiency by maize (Zea mays L.). International Journal of Applied Research and Studies (IJARS) 3(7): 2278-9480.

Bharath, T., Ch Vidyasagar, G. E., Praveen Rao, V. and Madhavi, A. (2017) Effect of integrated nutrient management on NPK uptakes and soil properties of maize in maize. Green Farming, 8(2): 409-412.

Black, C. A., (1965) Methods of Soil Analysis Part - II. Chemical and microbiological properties. Agronomy Monograph No. 9. 
American Society of Agronomy, Inc. Madison, Wisconsin, USA, 18-25.

Bouyoucos, G.J., (1927) The hydrometer as a new method for the mechanical analysis of soils. Soil Science.23, 343-353.

Choudhary, O. P., Bajwa, M. S., Josan, A. S. (1993) Effect of frequency of sodic and saline-sodic irrigations and gypsum on the build-up of sodium in soil and crop yields.Irrig. Sci., 14:21-26.

Davari, M. R.,Ram, M., andSharma,S.N. (2014). Direct, residual and cumulative effects of organic manures and bio fertilizers on yields, NPK uptake, grain quality and economics maize (Zea mays L.) under organic farming of maize (Zea mays L.) Journal of Organic Systems, 9(1): 23-34.

Ebrahimpour, F., Eidizadeh, K. H. and Damghani, A. M. (2011). Sustainable nutrient management in maize with integrated application of biological and chemical fertilizers. Int. J. Agric. Sci.1: 423-426.

Elwell, W. T. and Grindley, J. A. F. (1967). Atomic Absorption Spectrophotometry Pergam on Press Ltd., London, W-1.

Essan A.K. and Lattief, V.B., (2014.) Effect of Crop geometry, Intercropping Systems and Integrated Nutrient Management Practices on Productivity of maize (Zea mays L.) based Intercropping Systems. Research Journal of Agricultural and Biological Sciences 1(4), 295-302.

Fisher, R.A. (1955). Statistical methods and scientific induction. Journal of the royal statistical society series. 17,69-78.

Gupta, S., Swaroop, N., Thomas, T., Dawson, J. and Rao (2018) Effects of different levels of Phosphorus and Zinc on physicochemical properties of soil, growth and yield of Maize (Zea mays L.) International Journal of Chemical Studies, 6(3): 2105-2108.

Gyanendra, K., Ashwini, S., B.N. Tripathi, Ravindra, K.Tiwari,U. S. and Abhinav, K. (2015) Status of Available Micronutrients in Soils of Raebareli, Uttar Pradesh. Proceedings of National Conference on
Harmony with Nature in Context of Bioresources and Environmental Health .289-294.

Jackson, M. L. (1958) Soil chemical analysis Prentice Hall of India Ltd. New Delhi. Pp. 219-221.

Jackson, M. L. (1973) Soil chemical analysis Prentice Hall of India Ltd. New Delhi. Pp. 219-221.

Jat, S. L., Singh, A. K. and Sharma, H. B. (2014). Effects of planting and integrated nutrient management systems on root phenology and grain yield of maize. $3^{\text {rd }}$ International Agronomy Congress, Nov., New Delhi, India, Pp. 26-30.

Jaypraksh, M. A. (2005). Response of maize to different micronutrients and their application methods. Journal of Animal and Plant Sci, 22(1):122-129.

Kannan, R. L., Divya, M., Abhinaya, D., Krishna, R. L. and Krishna Kumar, S. (2013). Effect of integrated nutrient management on soil fertility and productivity in maize. Bulletin of Environment, Pharmacology and Life Science. 2(8): 61-67.

Kher P. and Minhas, S. (1991). Balanced use of inorganic fertilizer on maize (Zea mays L.) yield, nutrient uptake and soil fertility in alfisols. Karnataka J. Agri. Sci., 25(4): 423-426.

Kumar R., J. S. Bohra, Narendra Kumawat and Amitesh Kumar Singh. (2015). Fodder yield, nutrient uptake and quality of maize (Zea mays $\quad$ L.) as influenced by NPKS and $\mathrm{Zn}$ fertilization. Res. on Crops 16 (2): 243-249.

KumarT, Swaroop N., Rao P. S. and Thomas T., (2019) Effect of different levels of nitrogen and phosphorus on physicochemical properties of soil in maize (Zea mays L.) Cv. K-64 International Journal of Chemical Studies. 7(3): 1910-1914.

Kumar, M. A. A., Gali, S. K. and Hebsur, N. S., (2007) Effect of different levels of NPK on growth and yield parameters of maize. Karnataka Journal of Agricultural Sciences, 20, 41-43.

Kumar, V. P., Narendra, S., Ashish, M. and 
Reena, L. (2014) Effect of different dose of NPK and vermicompost on growth and yield attributes of maize [Zea mays (L.)] Cv. MM2255. Journal of Pharmacognosy and Phytochemistry, 7(1): 2830-2832.

Lindsay, W. L. and Norvell, W. A. (1978) Development of DTPA soil test for zinc, iron, manganese and copper. Soil Science Society of America Journal 42, 421-428.

Longchamp M., N. Angeli, M. Castrec-Rouelle (2016). Effects on the accumulation of calcium, magnesium, iron, manganese, copper and zinc of adding the two inorganic forms of selenium to solution cultures of Zea mays. Plant Physiology and Biochemistry 98.

Mahato P., Badoni, A. and. Chauhan, J. S. (2009) Effect of Azotobacter and Nitrogen on Seed Germination and Early Seedling Growth in maize (Zea mays L.) Researcher, 1(4):62-66.

Masih, A., Narendra, S., Parshottam, S., Vinod, P. and Yogesh, U., (2018) Effects of integrated nutrient management on chemical properties of soil in maize (Zea mays L.) Journal of Pharmacognosy and Phytochemistry 7(1): 1097-1099.

Meena, K. B., Alam, S., Singh, M. D. H., Bhat, M. A., Singh, A. K., Mishra, A. K. and Thomas, T.(2018) Influence of farmyard manure and fertilizers on soil properties and yield and nutrient uptake of maize (Zea mays L.) International Journal of Chemical Studies,6(3):386390.

Mishra, P., Tiwari, U. S., Pandey, H. P., Pathak, R. K. and Sachan, A. K., (2019)Effect of INM on physico-chemical properties of soil of maize (Zea mays) crop in Inceptisol of Central U.P. International Journal of Chemical Studies, 7(2):631635.

Motior rahman M., Abdou A. Soaud, Fareed H. AL Darwish Faruq Golam and M. SofianAzirun (2011) Growth and nutrient uptake of maize plants as affectedby elemental sulfur and nitrogen fertilizer in sandy calcareous soil. African Journal of Biotechnology. 10(60): 12882-12889.
Munsell, A. H. (1921) Munsell's description of his colour system, from a lecture to the American Psychological Association. American Journal of Psychology 23(2): 236-244.

Muthuvel, P., Udayasoorian, C., Natesan, R. and Ramaswamy, P. P. (1992) Introduction to Soil Analysis, Tamil Nadu Agricultural University Coimbatore641002.

Olsen, S. R., Cole, C. V., Watanabe, F. S. and Dean, L. A. (1954) Estimation of available phosphorus in soils by extraction with sodium bicarbonate (NaHCO3), U.S.D.A. Circular. 939: 1-19.

Onasanya, R. O., Aiyelari, O. P., Nwilene F. E. and Oyelakin, O. O. (2009) Growth and Yield response of maize (Zea mays L.) to different rates of nitrogen and phosphorus fertilizers in Southern Nigeria. World J. of Agri. Sci., 5(4): 400-407.

Rai, S. S., Sonani, V. V. and Patil, P. A., (2006) Study of economics of maize as influenced by different levels of nitrogen and phosphorus. International Journal of Scientific and Research Publications, 2250-3153.

Raun, P. A. and Johnson, P. K (1999)Effects of soil water content and foliar fertilization with nitrogen and phosphorous in late season on the yield and composition of

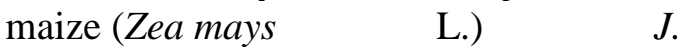
Agric.Sci., 18(3):599-603.

Ravankar, H.N., Bharambe, P.R., and Katore, J.R. (2009) Effect of long-term fertilization on yield and uptake of nutrients under maize (Zea mays L.) in Vertisols. J. Maharashtra agric. Univ., 16 (3): 185-188.

Ruth Njoroge,Abigael N. Otinga, John R. Okalebo, Mary Pepela and Roel Merckx (2018) Maize (Zea mays L.) Response to Secondary and Micronutrients for Profitable N, P and K Fertilizer Use in Poorly Responsive Soils. Agronomy 8: 49.

Saad Drissi,Abdelhadi A. Houssa, Ahmed Bamouh, Mohamed Benbella (2017) Response of Zea mays L. to zinc 
fertilization on a sandy soil under field and outdoor container conditions. Journal of the Saudi Society of Agricultural Sciences 16: 145-153.

Sarma, B., Bhattacharya, S. S., Gogoi, N., Paul, S. and Baroowa, B., (2015) Impact of $\mathrm{N}$ fertilization on $\mathrm{C}$ balance and soil quality in maize-dhaincha cropping sequence. Journal of Agri. Sci., 60(2): 135-148.

Selvakumar, G., Lenin, M., Thamizhiniyan, P. and Ravimycin, T. (2009) Response of bio-fertilizers on the growth and yield of maize (Zea mays L.) Recent Research in Science and Technology, 1(4):169-175.

Singh S.K., P. Dey, P.K. Sharma, Y.V. Singh, A.M. Latare, C.M. Singh, Deelip Kumar, Omkar Kumar, S.N. Yadav and S.S. Varma (2016) Primary and Cationic Micronutrient Status of Soils in Few Districts of Eastern Uttar Pradesh. Journal of the Indian Society of Soil Science, 64(4): 319-332.

Singh, B. R., and Haile, M., (2010) Impact of tillage and nitrogen fertilization on yield, nitrogen use efficiency of Eragrostis, Trotter and soil properties. Soil and Tillage Res. 94: 55-63.

Singh, R. N., (2017)Effect of higher application of nitrogen and potassium over recommended level on growth and yield attribute of late sown winter maize (Zea mays L.). crop research, Hissar,1(26): 77-84.

Snell, F. D. and Snell, C. T. (1949) Colorimetric Methods of Analysis, $3^{\text {rd }}$ edition, II D Van Nostrand Co. Inc., New York.

Subbiah, B. V. and Asiija, E. C. (1956) A rapid procedure for estimation of available nitrogen in soil. Current Science 25(8): 259-260.

Subehia, W. H., (2011) Effect of different nitrogen application on soil physicalchemical properties and yield of maize (Zea mays L.). Agri. Sci., 5(2): 14401447.

Tandon, H. L. S., (2009) Micronutrient hand book- from research to practical application. Fert. Dev. and Consultation org., New Delhi, India, 19-27.

Toth, S. J. and Prince, A. L. (1949) Estimation of cation exchange capacity and exchangeable $\mathrm{Ca}, \mathrm{K}$ and $\mathrm{Na}$ content of soil by flame photometer technique. Soil Sci., 67, 439-445.

Walkley, A. and Black, I. A. (1934) Estimation of soil organic carbon by the chromic acid titration method. Soil Science. 47: 29-38.

\section{How to cite this article:}

Dalavi Vishal Manohar, Narendra Swaroop, Tarence Thomas and Arun Alfred David. 2021. Effect of NPK Levels and Micronutrients with and without Liquid Biofertilizer on PhysicoChemical Properties of Soil in Maize. Int.J.Curr.Microbiol.App.Sci. 10(02): 3214-3227. doi: https://doi.org/10.20546/ijcmas.2021.1002.353 